\title{
e-ISSN $1983-0572$ \\ Predation on Species of Leptinopterus Hope (Coleoptera, Lucanidae) by Three Species of Reduviidae (Hemiptera, Heteroptera) in the Atlantic Forest, Brazil
}

\author{
Paschoal Coelho Grossi ${ }^{1}$, Ricardo Mitsuhiro Koike², Hélcio Reinaldo Gil-Santana ${ }^{3} \bowtie$
}

1. Universidade Federal do Paraná, Departamento de Zoologia, Curitiba, Paraná, Brazil, e-mail: paschoal.grossi@gmail.com. 2. Centro de Pesquisas de Historia Natural, Itaquera, São Paulo, São Paulo, Brazil, e-mail: rimitsukoike@hotmail.com. 3. Laboratório Nacional e Internacional de Referência em Taxonomia de Triatomíneos, Instituto Oswaldo Cruz, Rio de Janeiro, Brazil, e-mail: helciogil@uol.com.br; helciogil@ioc.fiocruz.br (Autor para correspondência ${ }^{\varpi}$ )

EntomoBrasilis 5 (2): 88-92 (2012)

\begin{abstract}
The natural occurrence of predation on Leptinopterus burmeisteri Arrow and Leptinopterus femoratus (Olivier) (Coleoptera, Lucanidae, Lucaninae) by Zelurus angularis (Stål) (Reduviinae), Apiomerus mutabilis Costa Lima, Seabra \& Hathaway and Apiomerus nigricollis Stål (Apiomerinae) (Hemiptera, Reduviidae), in the state of São Paulo, Brazil, is recorded. Additional data on the predatory habits of A. nigricollis are also presented here.
\end{abstract}

Keywords: Assassin bugs; Beetles; behavior; predation; prey.

\section{Predação de Espécies de Leptinopterus Hope (Coleoptera, Lucanidae) por Três Espécies de Reduviidae (Hemiptera, Heteroptera) na Floresta Atlântica, Brasil}

Resumo. Relata-se a ocorrência de predação natural de Leptinopterus burmeisteri Arrow e Leptinopterus femoratus (Olivier) (Coleoptera, Lucanidae, Lucaninae) por Zelurus angularis (Stål) (Reduviinae), Apiomerus mutabilis Costa Lima, Seabra \& Hathaway e Apiomerus nigricollis Stål (Apiomerinae) (Hemiptera, Reduviidae) no Estado de São Paulo, Brasil. Dados adicionais sobre hábitos predadores de A. nigricollis são apresentados também.

Palavras-chave: Besouros; comportamento; percevejos predadores; predação; presa.

$\mathbf{R}$ eduviidae is the second largest family of true bugs (Hemiptera, Heteroptera) and all of its members are predators. The Triatominae are the exception because of their blood-sucking habits. Despite the lack of consensus about the suprageneric classification of Reduviidae, more than 20 subfamilies are recognized. Harpactorinae is the largest subfamily and is represented by the tribes Apiomerini and Harpactorini in the New World (CAPriles 1990; SchuH \& Slater 1995; Forero et al. 2008; Gil-SANTANA \& Forero 2009).

The largest and probably best known genus of Apiomerini is Apiomerus Hahn, with more than 100 species (CAPRILES 1990; ForERo et al. 2010). These diurnal predators live on plants, and at least some use sticky material on the anterior tibiae to hold prey (Schuh \& Slater 1995; Gil-Santana \& Forero 2010). Many species of Apiomerini have been revealed to be polyphagous, attacking pest insects as well as useful insects (CosTA LiMA 1940b; Gil-Santana et al. 2003). Apiomerus spp. prey upon insects of different orders (Marques et al. 2003), including Coleoptera (GiL-SANTANA 2002), but substantial predation activity has been recorded on bees (Hymenoptera, Apidae), such as Apis mellifera Linnaeus (Apinae, Apini) (Costa Lima 1940b; MARQUes et al. 2003) and in particular stingless bees (Apinae, Meliponini) (Silva \& Gil-Santana 2004; Gil-Santana et al. 2006). Indeed, they are commonly known as bee-killers or bee-assassins, due to their recorded attraction to and predation on bees (BERNIKER et al. 2011). Species of Apiomerus have also been recognized as mimics of meliponine bees (Hogue 1993; GiL-Santana et al. 2003).
Apiomerus nigricollis Stål has been recorded ranging from the states of Rio de Janeiro to the state of Rio Grande do Sul in Brazil and ranging from the provinces of Misiones to the province of Entre Rios in Argentina (CoSTA LiMA et al. 1951; CARPINTERO 1981). In Argentina, A. nigricollis has been found in caves of Dasypus sp. ("armadillos"), together with Triatoma rubrovaria (Blanchard) (Reduviidae, Triatominae), which was considered to be a possible prey for this apiomerine (CARPINTERO 1981).

Apiomerus mutabilis Costa Lima, Seabra \& Hathaway has been recorded ranging from the states of Rio de Janeiro to the state of Santa Catarina in Brazil and in the province of Misiones, Argentina (Costa Lima et al. 1951). Under artificial conditions adults of $A$. mutabilis have been regularly fed with Trigona sp. (Apinae, Meliponini) (Gil-SANTANa \& Forero 2010).

Many, if not most members of Reduviinae are thought to be general insect or arthropod predators. Most are nocturnal (ScHuH \& SLATER 1995). The most speciose genus of Reduviinae in the New World is Zelurus Hahn with more than 120 recognized species (CAPRILES 1990). Many species of Zelurus are recognized to be mimics of wasps of the genus Pepsis Fabricius (Hymenoptera, Pompilidae) (Costa Lima 1940a; Hogue 1993; Vardy 2000; GILSANTANa et al. 2003).

There are few records of the predatory habits of Zelurus spp. Some species of Zelurus have been observed preying on nymphs of some species of Triatominae, both under natural and under laboratory conditions (CARPINTERo 1981; COSCARÓN et al. 1999). 
Zelurus sp. was reported to be a predator of harvestemen (Goniosoma sp., Arachnida, Opiliones, Gonyleptidae) in almost all the caves visited in the study of MACHADO et al. (2003), and Goniosoma spelaeum (Mello-Leitão) were observed to be the prey of Zelurus travassosi (Costa Lima) in caves (Trajano \& BichuetTE 2010). Zelurus travassosi is also the most important predator of the trogloxene G. spelaeum in the state of São Paulo and the troglophile Daguerreia inermes Soares \& Soares (Opiliones, Gonyleptidae), in the state of Paraná, Brazil (MAchADO et al. 2003).

Zelurus angularis (Stål) was originally recorded from "Brasilia" (i. e. Brazil) (STÅL 1872). Further records based on only a few specimens were attributed to "Itatiaia" (COSTA LIMA, 1940a; LENT \& Wygodzinsky 1945), Nova Friburgo (Gil-SANTANa \& ZERAiK 2002), in the state of Rio de Janeiro and São Paulo, in the state of São Paulo (LENT \& WYGODZINSKY 1945).

The stag beetles are a cosmopolitan family of Coleoptera (Scarabaeoidea), with greatest diversity in tropical regions, especially in Asia (FuJITA 2010). Four subfamilies have been recognized and representatives of all of them can be found in the Neotropical region (PAULSEN 2010), where about 40 genera and 210 species occur.

The Brazilian species are almost all distributed in the Atlantic Forest biome (LÜDERWALdT 1935; Grossi \& PaUlsen 2009; Grossi 2009), although one genus is exclusive to the Amazonian region (VuLCANo \& Pereira 1961; RAtcliffe 1984) and some species have been collected in some Cerrado (savanna) areas (Grossi - unpublished data). The generic classification of the South American lucanids is under analysis by one of us (PCG) and some proposals have recently been published (Grossi \& VAZ-DE-Mello 2007; Grossi \& PAULSEN 2009), but more work is needed. There is almost no information about the natural history of the species from South America and only for a few genera is there any information on adult and larval feeding habits (ONore \& BARTOLOZZI 2008; Mondaca \& PAULSEN 2008; Grossi 2009).

In Brazil and Chile for example, adults usually feed on the sap flows of some plant species and sometimes many specimens can be found fighting, or there may be males guarding females and in mating. This condition is also commonly observed among other Coleoptera families and other insects orders (Grossi 2009). Through this kind of behavior, individuals are often exposed to predation by other kinds of animals and also by other insects. One of these groups is the genus Leptinopterus Hope, for which all the species occur in Brazil and three of them also in adjacent areas of Argentina and Paraguay. The genus is represented by 30 species and seems to be distributed almost exclusively in the Atlantic Forest. The adults are diurnal and the larvae feed on non-decayed dead wood (Grossi 2009).

In the present paper, the natural occurrence of predation on two species of Leptinopterus Hope (Coleoptera, Lucanidae, Lucaninae) by $Z$. angularis (Reduviinae), A. mutabilis and $A$. nigricollis (Apiomerinae) (Hemiptera, Reduviidae) is recorded for the first time.

Additional data on the predatory habits of $A$. nigricollis are also presented here.

\section{MATERIAL AND METHODS}

The field observations were made in the municipality, Arujá ( $23^{\circ} 21^{\prime} 14^{\prime \prime}$ S, $\left.46^{\circ} 19^{\prime} 49^{\prime \prime} \mathrm{W}\right)$, state of São Paulo, Brazil during the austral summer, between the months of October 2009 and January 2010, at an elevation of nearly $800 \mathrm{~m}$ above sea levels, over a total sampling area of around 40 ha. The area studied is a well preserved fragment of secondary Atlantic forest with native and exotic herbaceous and arboreal species such as Quercus sp. (Fagaceae). The specimen collection took place in a sloping area near at Quercus sp. plantation at the edge of the area of native vegetation, with a difference in level of 50 meters from the lowest point to the highest point. Specimens were collected on almost all the weekends over the period mentioned above. The insects were observed alive and the observations were registered.

Leptinopterus femoratus (Olivier) seems to be a common species in that region, and was commonly found feeding on sap flows in the lower part of the trees (Quercus acutissima Carruthers), at about 1.50 to 3.0 meters from the ground and was observed from October to December. More than 20 dead specimens were found on the ground, in some cases exactly at the moment of the predation (Figure 1) and more than 70 specimens were collected per year. The species L. femoratus was also observed feeding on fermented bananas that were used to attract this and other Coleoptera species (Figure 2). Among the smaller males, the so called "mesodont" and "amphiodont" forms seemed to be driving away by the presence of the Reduviidae and were sometimes seen trying to find a lurking place below the bark of the trees or inside a cavity (Figures 3-4). However, the larger males ("telodont" forms) usually tried to fight with the Reduviidae, which mean that the attack was always slower, but actually still occurred (Figure 1).

The species $L$. burmeisteri seems to be an uncommon species in that region, given that fewer than 50 specimens were found over the same period, including the fragments. This species was not attracted by fermented fruits and was not observed in the low parts of the trees, but only at the highest parts, between 10 and 15 meters above the ground. The specimens were collected from mid November to the beginning of January. If it had not been a target for the predation by the Reduviidae, it might never have been seen at the tree tops. Almost all the specimens were found dead on the ground and one small male was seen under observation by a Reduviidae specimen.

Additional data on the predatory habits of $A$. nigricollis, recorded by the junior author in the city of Nova Friburgo $\left(22^{\circ} 17^{\prime} \mathrm{S} ; 42^{\circ}\right.$ $29^{\prime}$ W), at around $1000 \mathrm{~m}$ above sea level, in the state of Rio de Janeiro, Brazil, are also presented here (Figures 5-6).

The Reduviidae species were identified by the second junior author (HRG-S), in accordance with Costa Lima et al. (1951) and Gil-Santana \& Forero (2010) (A. mutabilis), StÅL (1860) and Costa Lima et al. (1951) (A. nigricollis) and, Costa Lima (1940a) and LENT \& WYGODZINSKY (1945) (Z. angularis).

The Lucanidae were identified by the senior author (PCG), in accordance with LÜDERWALDT (1935) and Mizunuma \& NAGAI (1994) and in conformity with type specimens loaned from Martin Luther University Halle-Wittenberg (MLUH). In addition, they were compared with previously identified material in some Brazilian collections. Voucher specimens of the suited Reduviidae are deposited at in the Entomological Collections of the "Museu Nacional da Universidade Federal do Rio de Janeiro (MNRJ), Rio de Janeiro, and the Lucanidae in "Coleção Padre Jesús Santiago Moure” (DZUP), Curitiba, Paraná.

\section{RESULTS AND DISCUSSION}

The specimens of Leptinopterus were observed feeding on sap flows of the sawtooth oak, Q. acutissima (Fagaceae). Reduviidae species were seen at these sites, exhibiting the behavior of sitting and waiting for the opportunity to catch the stag beetle specimens (Figures 2-4). The male specimens of Leptinopterus are sometimes bigger than the Reduviidae, although they can still kill the beetle by introducing the rostrum ventrally between the line of the pronotum and the elytra or between the head and the pronotum (Figure 1). Many fragments of both species of Leptinopterus were found on the ground below the trees, thus indicating that the Reduviidae are efficient predators of Lucanidae species. Although there are no pictures of Apiomerus preying the Lucanidae, the same were observed in the field during the predation. 
Additionally, natural predation of an unidentified Curculionidae by Apiomerus nigricollis, under natural conditions, in the city of Nova Friburgo $\left(22^{\circ} 17^{\prime} \mathrm{S} ; 42^{\circ} 29^{\prime} \mathrm{W}\right)$, at around $1000 \mathrm{~m}$ above sea level, in the state of Rio de Janeiro, in November 2010, is recorded (Figure 5). The predator $A$. nigricollis has also been observed to feed on Trigona sp. (Hymenoptera, Apidae, Apinae, Meliponini) under artificial conditions (Figure 6), just like $A$. mutabilis (GIL-SANTANA \& ForERO 2010).

Only more extensive future fieldwork would clarify whether the significance of predation on Leptinopterus species by $Z$. angularis, A. mutabilis and A. nigricollis is that there is an occasional relationship, or whether this genus is a frequent prey for one or all of these Reduviidae.

\section{ACKNOWLEDGEMENTS}

PCG is supported by a CNPQ postdoctoral grant, process number 150392/2011-7.

\section{REFERENCES}

Berniker, L, S. Szerlip, D. Forero \& C. Weirauch, 2011. Revision of the crassipes and pictipes groups of Apiomerus Hahn (Hemiptera: Reduviidae: Harpactorinae). Zootaxa, 2949: 1-113.

Capriles, J.M., 1990. Systematic catalogue of the Reduviidae of the World. Caribbean Journal of Science, Special publication n. 1. Puerto Rico, University of Puerto Rico, 694p.

Carpintero, D.J., 1981. Sobre Reduviidae predators de Triatominae. Comunicaciones del Museo argentino de ciências naturales Bernardino Rivadavia, Tomo 1, 6: 83-92.

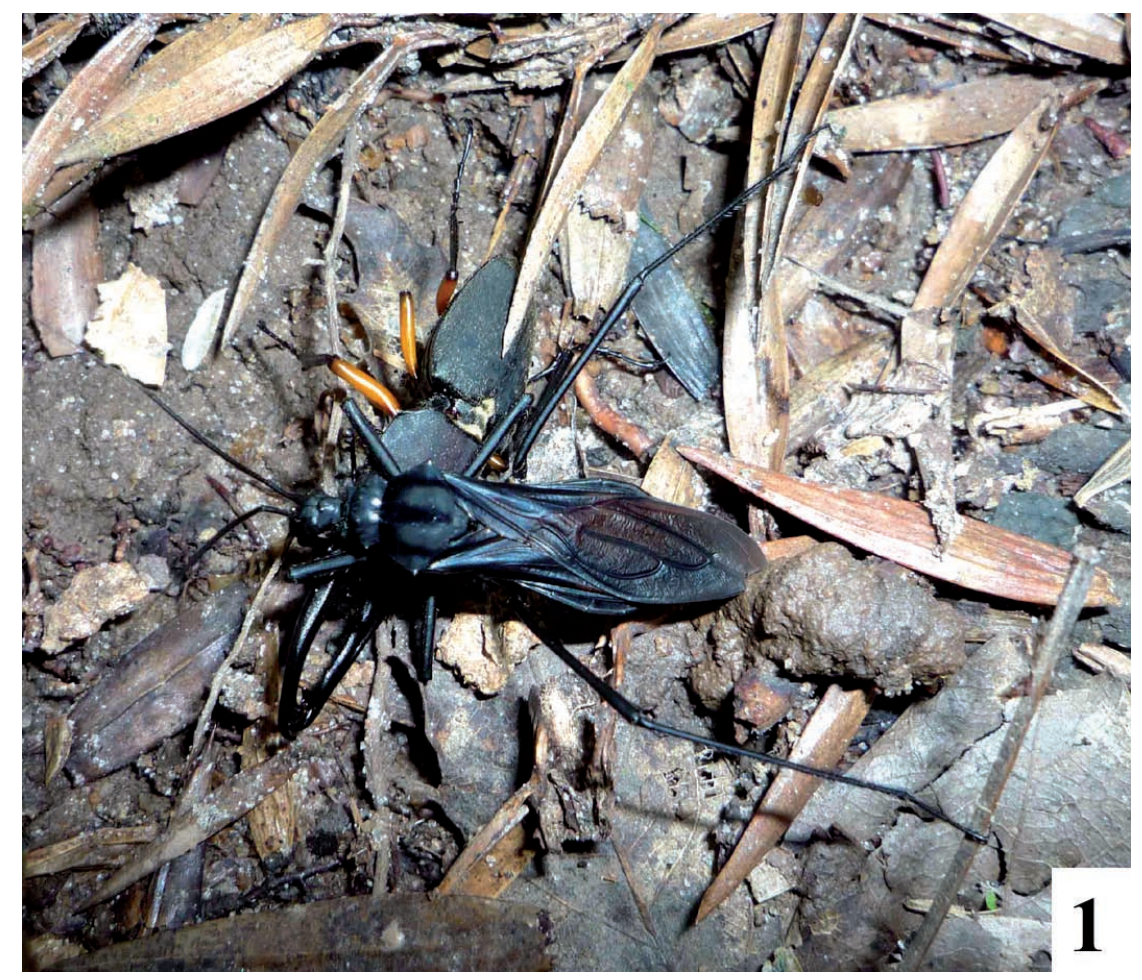

Figure 1. Zelurus angularis preying on a larger male of Leptinopterus femoratus.

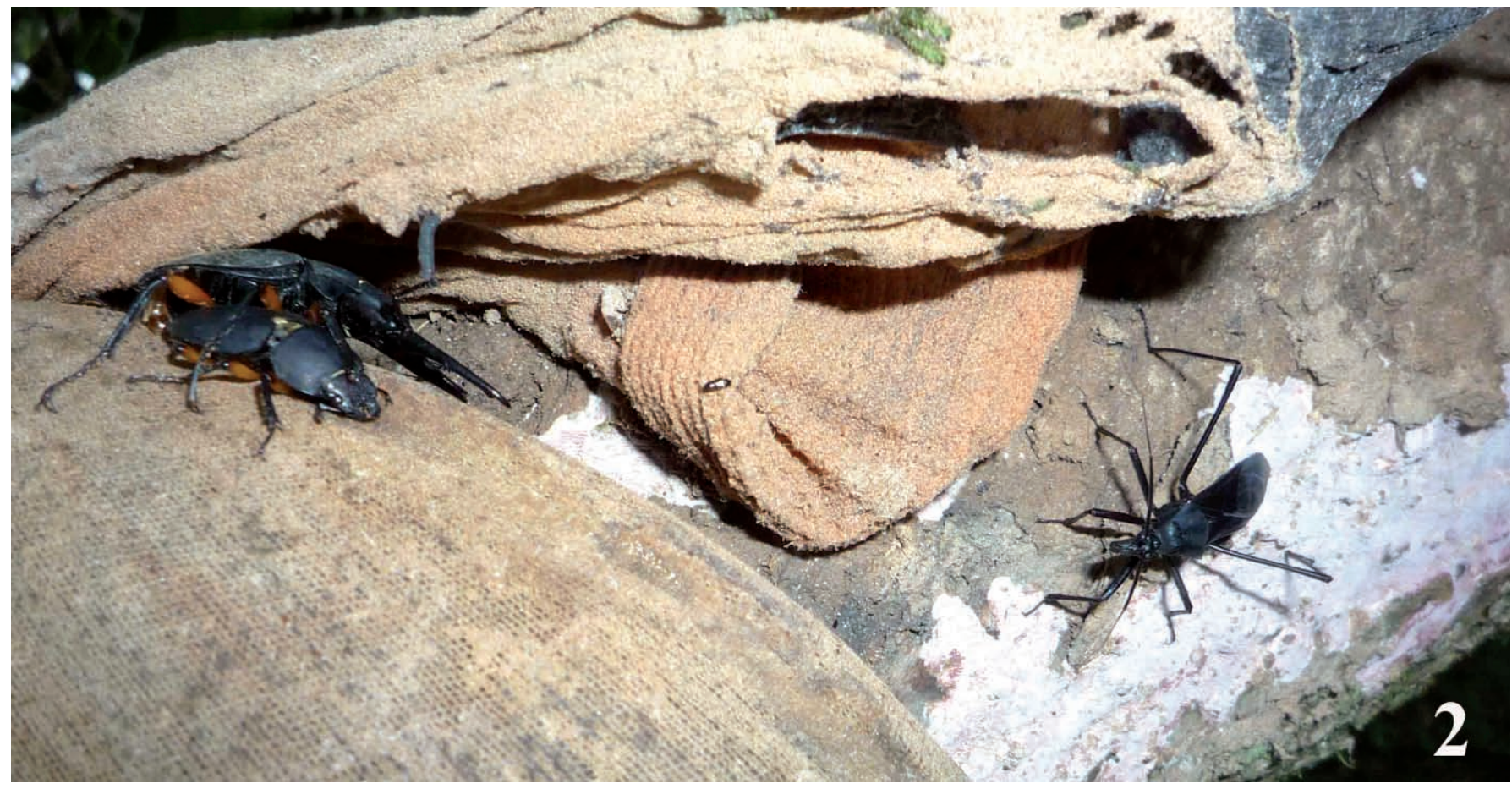

Figure 2. Zelurus angularis and a couple of Leptinopterus femoratus: the reduviid escaped after this photo was taken. 

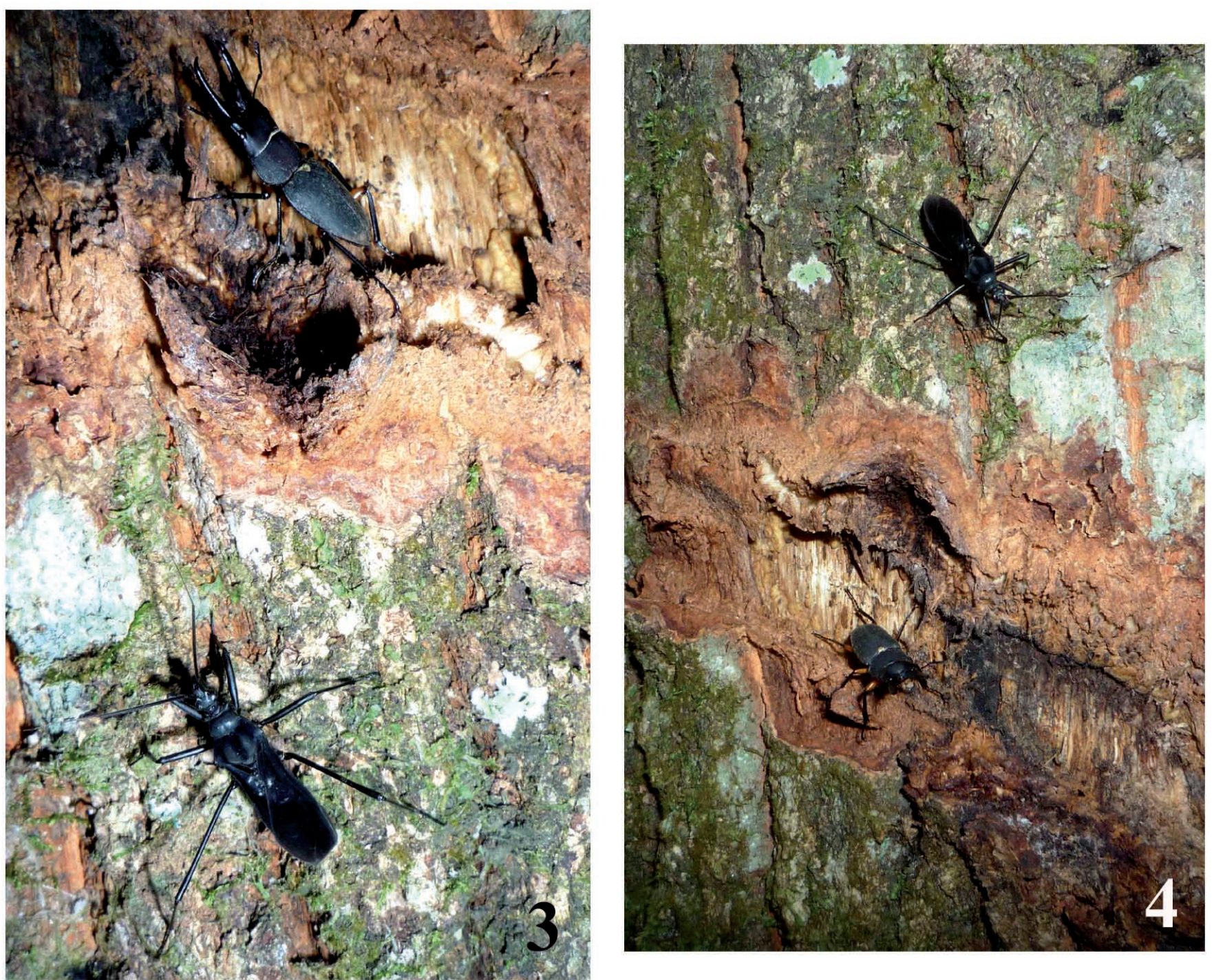

Figures 3-4. Zelurus angularis and a medium-sized Leptinopterus femoratus trying to hide under the tree cutting.
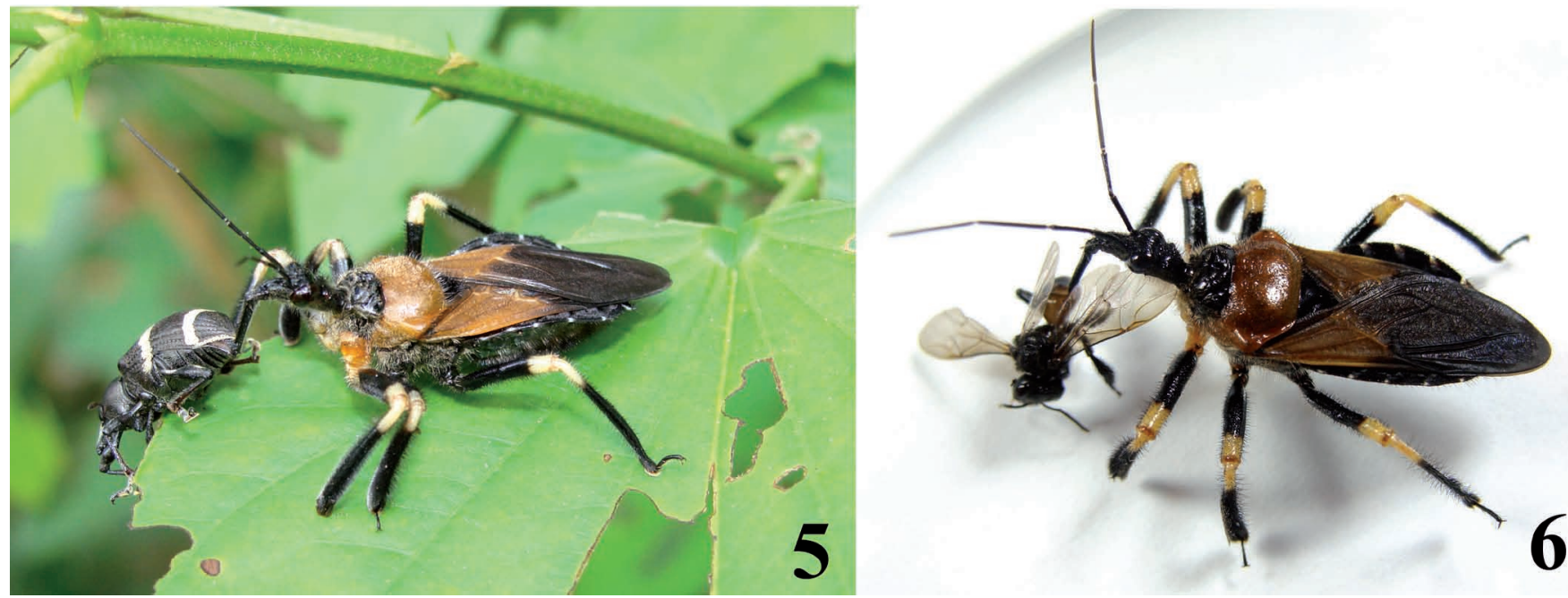

Figures 5-6. Apiomerus nigricollis (6) preying on a curculionid beetle and (7) preying on a meliponine bee.

Coscarón, M.C, M.S. Loiácono \& L. de Santis, 1999. Predators and parasitoids. Predadores e parasitóides. p. 891-924. In: Carcavallo, R.U, I.G. Girón, J. Jurberg \& H. Lent (Eds.). Atlas of Chagas' Disease in the Americas. Atlas dos vetores da Doença de Chagas nas Américas. Vol. 3, Rio de Janeiro, Editora Fiocruz, 1215p.

Costa Lima, A.M., 1940a. Sobre as espécies de Spiniger (Hemiptera: Reduviidae). Memórias do Instituto Oswaldo Cruz, 35: 1-129.

Costa Lima, A.M., 1940b. Insetos do Brasil. V. 2. Hemípteros. Rio de Janeiro, Escola Nacional de Agronomia, 351p.

Costa Lima, A.M., C.A.C. Seabra \& C. R. Hathaway, 1951. Estudo dos Apiômeros (Hemiptera: Reduviidae). Memórias do Instituto Oswaldo Cruz, 49: 273-442.

Forero, D., L. Berniker \& S. Szerlip, 2010. A polychromatic new species of Apiomerus (Hemiptera:Reduviidae:Harpactorinae) from Central America. Zootaxa, 2522: 44-6o.

Forero, D., H.R. Gil-Santana \& P.H. van Doesburg, 2008. Redescription of the Neotropical genus Aristathlus (Heteroptera, Reduviidae, Harpactorinae), p. 85-103. In: 
Grozeva, S. \& N. Simov (Eds.). Advances in Heteroptera Research, Festschrift in Honour of $80^{\text {th }}$ Anniversary of Michail Josifov. Sofia-Moscow, Pensoft Publishers, 417p.

Fujita, H., 2010. The lucanid beetles of the world. Mushi-Sha's iconographic series of insects, 6: $488 \mathrm{pp}$.

Gil-Santana, H.R. 2002. Predação de Lagria villosa Fabricius, 1783 (Coleoptera: Lagriidae) por Apiomerus nigrilobus Stål, 1872 (Hemiptera: Reduviidae: Apiomerinae) em Cabo Frio, Estado do Rio de Janeiro, Brasil. Entomología y Vectores, 9: 201-208.

Gil-Santana, H.R., Costa L.A.A., D. Forero \& S.O. Zeraik, 2003. Sinopse dos Apiomerini, com chave ilustrada para os gêneros (Hemiptera-Heteroptera, Reduviidae, Harpactorinae). Publicações Avulsas do Museu Nacional, 97: 1-24.

Gil-Santana, H.R. \& D. Forero, 2009. A new species of Notocyrtus, a new synonym of Coilopus, and new records and notes on other Harpactorini (Hemiptera: Heteroptera: Reduviidae: Harpactorinae). Zootaxa, 2148: 55-67.

Gil-Santana, H.R. \& D. Forero, 2010. Taxonomical and biological notes on Neotropical Apiomerini (Hemiptera: Heteroptera: Reduviidae: Harpactorinae). Zootaxa, 2331: 57-68.

Gil-Santana, H.R. \& S.O. Zeraik, 2002. Reduviidae de Nova Friburgo, Estado do Rio de Janeiro, Brasil (HemipteraHeteroptera). Entomología y Vectores, 9: 295-299.

Gil-Santana, H.R., S.O. Zeraik \& P. Milano, 2006. Notas sobre algumas espécies de Apiomerus Hahn do Brasil (Heteroptera: Reduviidae: Harpactorinae: Apiomerini). Boletín Sociedad Entomológica Aragonesa, 39: 213-218.

Grossi, P.C. \& F.Z. Vaz-de-Mello, 2007. A new species of Metadorcinus Kriesche (= Beneshius Weinreich) from Brazil with notes on this genus (Coleoptera: Scarabaeoidea: Lucanidae). Zootaxa, 1478, 49-59.

Grossi, P.C. \& M.J. Paulsen, 2009. Generic limits in South American stag beetles: taxa currently misplaced in Sclerostomus Burmeister (Coleoptera: Lucanidae: Lucaninae: Sclerostomini). Zootaxa 2139: 23-42.

Grossi,P.C., 2009. Description of two new species of Leptinopterus Hope (Coleoptera: Lucanidae: Lucaninae) with notes on the taxonomy and natural history of the genus. Zootaxa, 2172: $32-44$.

Hogue, C.H., 1993. Latin American Insects and Entomology, University of California Press, Los Angeles, 536p.

Lent, H. \& P. Wygodzinsky, 1945. Contribuição ao conhecimento do gênero Zelurus Hahn (Spiniger auct.) (Reduviidae, Hemiptera). Memórias do Instituto Oswaldo Cruz, 43: 205269.

Lüderwaldt, H., 1935. Monographia dos lucanideos brasileiros. Revista do Museu Paulista, 19: 447-574.

Machado, S.F, R.L. Ferreira \& R.P. Martins, 2003. Aspects of the population ecology of Goniosoma sp. (Arachnida Opiliones Gonyleptidae) in limestone caves in southeastern Brazil. Tropical Zoology, 16: 13-31.
Marques, O.M, H.R. Gil-Santana, A.C.A. Magalhães \& A.A.L. Carvalho, 2003. Predação de Apiomerus lanipes (Fabricius, 1803) (Hemiptera: Reduviidae) sobre Apis mellifera (Linnaeus, 1758) (Hymenoptera: Apidae), no Estado da Bahia, Brasil. Entomología y Vectores, 10: 419-429.

Mizunuma, T., \& S. Nagai, 1994. The Lucanid Beetles of the World. Mushi Sha, Tokyo, $337 \mathrm{pp}$.

Mondaca, J.E. \& M.J. Paulsen, 2008. Revision of the genus Apterodorcus Arrow (Coleoptera: Lucanidae: Lucaninae) of southern South America. Zootaxa, 1922: 21-32.

Onore, G. \& L. Bartolozzi, 2008. Description of the larvae of Sphaenognathus (Chiasognathinus) gaujoni (Oberthüri, 1885) and $S$. (C.) xeropilus Bartolozzi \& Onore, 2006 (Coleoptera: Lucanidae), with observations about their altitudinal range extension. Biodiversity of South America, I. Memoirs on Biodiversity, 1: 399-406.

Paulsen, M.-J., 2010. The stag beetles of southern South America (Coleoptera: Lucanidae). Bulletin of the University of Nebraska State Museum 24, 1-148.

Ratcliffe, B.C., 1984. A Review of the Penichrolucaninae with Analyses of Phylogeny and Biogeography, and Description of a Second New World Species from the Amazon Basin (Coleoptera: Lucanidae). Quaestiones Entomologicae, 20: 60-87.

Silva, A.C. \& H.R. Gil-Santana, 2004. Predation of Apiomerus pilipes (Fabricius) (Hemiptera, Reduviidae, Harpactorinae, Apiomerini) over Meliponinae bees (Hymenoptera, Apidae) in the State of Amazonas, Brazil. Revista Brasileira de Zoologia, 21: 769-774.

Schuh, R.T. \& J.A. Slater, 1995. True bugs of the World (Hemiptera: Heteroptera). Classification and natural history. Ithaca, Cornell University Press, 336p.

Stål, C., 1860. Bidrag till Rio de Janeiro-Traktens HemipterFauna. Kongliga Svenska Vetenskaps-Akademiens Handlingar, 2: 1-84.

Stål, C., 1872. Enumeratio Hemipterorum. II. Kongliga Svenska Vetenskaps-Akademiens Handlingar, 10: 66-128.

Trajano, E. \& M.E. Bichuette, 2010. Diversity of Brazilian subterranean invertebrates, with a listo f troglomorphic taxa. Subterranean Biology, 7: 1-16.

Vulcano,M.A.\&F.S.Pereira, 1961.Asubfamília Penichrolucaninae (Col. Lucanidae) representada em América. Studia Entomologica, 4: 471-480.

Vardy, C.R., 2000. The New World tarantula-hawk wasp genus Pepsis Fabricius (Hymenoptera: Pompilidae). Part 1. Introduction and the $P$. rubra species-group. Zoologische Verhandelingen, 332: 1-86.

\section{Recebido em: 15/12/2011}

Aceito em: 12/02/2012

\section{Como citar este artigo:}

Grossi, P.C., R.M. Koike \& H.R. Gil-Santana, 2012. Predation on Species of Leptinopterus Hope (Coleoptera, Lucanidae) by Three Species of Reduviidae (Hemiptera, Heteroptera) in the Atlantic Forest, Brazil. EntomoBrasilis, 5(2): 88-92.

Acessível em: http://www.periodico.ebras.bio.br/ojs/index.php/ebras/article/view/199
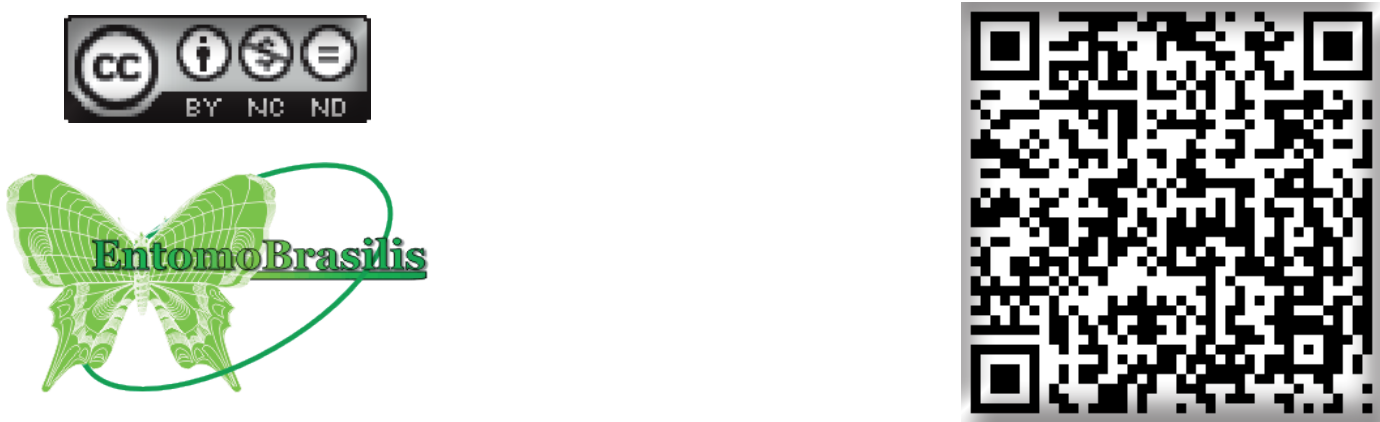